\title{
Analysis of Virulence Factors of Legionella pneumophila
}

\author{
JÖRG HACKER, MANFRED OTT, EVA WINTERMEYER, \\ BIRGIT LUDWIG, and GUNTER FISCHER ${ }^{1}$
}

Theodor-Boveri-Institut für Biowissenschaften der Universität Würzburg, Lehrstuhl für Mikrobiologie, 8700 Würzburg, Germany

${ }^{1}$ MPG Arbeitsgruppe „Enzymologie der Peptidbindung“, Biotechnicum, $4050 \mathrm{Halle} / \mathrm{Saale}$, Germany

\section{With 3 Figures}

\section{Summary}

Legionella pneumophila, the causative agent of Legionnaires' disease is a facultative intracellular bacterium, which in the course of human infection multiplies in lung macrophages predominantly manifesting as pneumonia. The natural habitat of Legionella is found in sweet water reservoirs and man-made water systems. Virulent L.pneumophila spontaneously convert to an avirulent status at a high frequency. Genetic approaches have led to the identification of various L.pneumophila genes. The mip (macrophage infectivity potentiator) determinant remains at present the sole established virulence factor. The Mip protein exhibits activity of a peptidyl prolyl cis trans isomerase (PPlase), an enzyme which is able to bind the immunosuppressant FK506 and is involved in protein folding. The recently cloned major outer membrane protein (MOMP) could play a role in the uptake of legionellae by macrophages. Cellular models are useful in studying the intracellular replication of legionellae in eukaryotic cells. Human cell lines and protozoan models are appropriate for this purpose. By using U 937 macrophage-like cells and Acanthamoeba castellanii as hosts, we could discriminate virulent and avirulent $L$.pneumophila variants since only the virulent strain was capable of intracellular growth at $37^{\circ} \mathrm{C}$. By using these systems we further demonstrated that a hemolytic factor cloned and characterized in our laboratory, legiolysin (lly), had no influence on the intracellular growth of L.pneumophila.

\section{Zusammenfassung}

Legionella pneumophila, der Erreger der Legionärskrankheit, ist ein fakultativ intrazelluläres Bakterium. Im Zuge einer Infektion der menschlichen Atemwege, die sich als Pneumonie manifestiert, vermehren sich Legionellen intrazellulär in Lungenmakrophagen. Legionellen kommen natürlicherweise in Süßwasserhabitaten, einschließlich Wasserleitungsanlagen vor. Aus virulenten $L$. pneumophila-Stämmen können spontan und mit hoher Frequenz avirulente Varianten entstehen. Genetische Arbeiten führten zur Identifizierung verschiedener L. pneumophila-Gene. Bisher konnte nur die mip („macrophage infectivity potentiator")-Determinante eindeutig als Virulenzgen identifiziert werden. Das Mip-Protein bildet eine Peptidyl-Prolyl-cis-trans-Isomerase (PPIase)-Aktivität aus, die durch Zugabe des 
Immunsuppressivums FK506 gehemmt werden kann. Das „major outer membrane protein “ (MOMP), dessen genetische Determinante ebenso kürzlich kloniert wurde, ist an der Aufnahme von Legionellen durch Makrophagen beteiligt. Zelluläre Modellsysteme werden zur Untersuchung der intrazellulären Vermehrung von Legionellen in eukaryontischen Zellen herangezogen. Geeignet sind humane Zellinien, aber auch Protozoen-Modelle finden Verwendung. Mit Hilfe der Makrophagen-ähnlichen Zellinie U 937 und Acanthamoeba castellanii als Wirtszellen konnten wir virulente von avirulenten $L$. pneumophila-Stämmen unterscheiden, da sich bei $37^{\circ} \mathrm{C}$ nur virulente Stämme intrazellulär vermehren. Ferner konnten wir mit diesen Modellen zeigen, daß das Legiolysin (Lly), ein hämolytischer Faktor, der in unserem Labor kloniert und charakterisiert wurde, keinen Einfluß auf die intrazelluläre Vermehrung von L.pneumophila nimmt.

\section{Legionella pneumophila, the Causative Agent of Legionnaires' Disease}

L.pneumophila was first described in 1977 , during the year following the outbreak of epidemic pneumonia in Philadelphia in 1976 (36). The causative agent of the disease, which was termed Legionnaires' disease was identified as a Gram-negative rodlike bacterium with special growth requirements in the laboratory (55). In addition to L.pneumophila, 31 species of the genus Legionella have been described in the meantime, and half of them have been reported to be pathogenic for humans (13). The clinical manifestation of Legionella infections is pneumonia, but also a non-pneumonic disease, termed Pontiac fever, is due to Legionella infections.

Legionellae are found ubiquitously in sweet water reservoirs, where the presence of protozoa supports their growth (45). Infection of humans starts with the inhalation of aerosolized water-borne legionellae. Elderly and immunocompromized persons are highly susceptible to infection by legionellae. In the course of infection, which is accompanied by high fever, legionellae multiply in lung macrophages, leading to severe tissue damage $(13,55)$. Lethal consequences of Legionnaires' disease have been reported quite often, especially in the case of nosocomial outbreaks (41). Transmission from human to human has not been observed.

Legionellae spontaneously convert to an avirulent status, with a relatively high frequency (8). Avirulent variants which can be enriched by culturing on special laboratory media, differ from their virulent parents in numerous aspects. Morphologically, avirulent strains tend to display an enlongated cell shape (39), they furthermore show reduced serum resistance (7) and survival in aerosols (12). Strikingly, the capability to replicate intracellularily in either monocytes and macrophages or even in protozoa is lost $(26,38,42,49)$. Virulence of legionellae is assessed by intranasal or intraperitoneal infection of guinea pigs which seem to have been the only appropriate animal model to date $(2,49)$. Little is presently known about the factors contributing to the virulence of legionellae. The comparison of virulent and avirulent counterparts is an effective approach which results in a better understanding of Legionella pathogenicity. In addition to this approach, genetic attempts to clone and characterize putative Legionellaspecific virulence factors have been undertaken in recent years.

\section{The Mip Protein: A Legionella Virulence Factor with an Unusual Enzymatic Activity}

Several groups have reported about the construction of Legionella genomic libraries from patient isolates $(17,20,21)$. Various L.pneumophila-specific proteins have been cloned in E. coli $\mathrm{K}-12$. The most intensively studied protein is the so-called Mip ("macrophage infec- 
tivity potentiator") factor, a membrane-associated protein of $24 \mathrm{kDa}(15,17)$. It was conclusively demonstrated that the ability of Mip-negative mutants of L.pneumophila to invade eukaryotic cells was reduced by a factor of 100 when compared to Mip-positive cells (11). In addition, a mutation in the mip gene resulted in an attenuation of virulence as estimated in the guinea pig model (10). In vivo and in vitro virulence could be restored by reintroduction of functionally active mip sequences into the Mip-negative mutants.

The mip sequences are highly conserved among virulent and non-virulent strains of L. pneumophila (Table 1, ref. 9). It exhibits homology with mip-like genes of other Legionelta species $(1,9)$. Interestingly, genes which show a degree of about $50 \%$ homology to the mip determinant of $L$.pneumophila are also located on the genomes of other pathogenic bacteria like Chlamydia trachomatis, Neisseria meningitidis and Pseudomonas aeruginosa, thus furthering the argument of a common mechanism for these proteins in the pathogenesis of bacteria.

The amino acid sequence from the C-terminal part of the Mip protein also shares homologies with eukaryotic FK506 binding proteins (FKBPs) which, together with ciclophilins, form the substance class of immunophilins. They are involved in the regulation of early T-cell activation (47). The immunophilins are able to bind the immunosuppressants, FK506 (in the case of FKBPs) and ciclosporin (in the case of ciclophilins). In addition, they exhibit peptidly prolyl cis trans isomerase (PPlase), activity, i. e. they isomerize cis peptidyl-proline bonds to the trans configuration and may play a role in protein folding (19, 30). Consequently, we expressed the Mip factor in a vector system suitable for the isolation and characterization of the protein. To our surprise, we were able to show that Mip indeed

Table 1. Homology between the amino acid sequence of the Mip protein of L.pneumophila strain Philadelphia I (data from ref. 18) and sequences and open reading frames (ORFs) of various organisms

\begin{tabular}{|c|c|c|c|}
\hline Organism & Protein & Homology & References \\
\hline $\begin{array}{l}\text { Legionella pneumophila } \\
\text { strain Wadsworth }\end{array}$ & Mip & $99.6 \%$ & 16 \\
\hline $\begin{array}{l}\text { Legionella pneumophila } \\
\text { strain U21 S6 }\end{array}$ & Mip & $99.6 \%$ & $\begin{array}{l}\text { Ludwig, } \\
\text { unpublished data }\end{array}$ \\
\hline Legionella micdadei & Mip-like protein & $88.4 \%$ & 1 \\
\hline Neisseria meningitidis & $\begin{array}{l}\text { ORF in the vicinity } \\
\text { of pili genes }\end{array}$ & $59.8 \%$ & 43 \\
\hline Chlamydia trachomatis & L2-Protein ${ }^{1}$ & $56,2 \%$ & 32 \\
\hline Pseudomonas aeruginosa & $\begin{array}{l}\text { ORF in the vicinity of } \\
\text { alginate synthesis genes }\end{array}$ & $50,0 \%$ & 28 \\
\hline Man & FKPB of $\mathrm{T}$ cells ${ }^{2}$ & $55,2 \%$ & 33,48 \\
\hline Saccharomyces cerevisiae & FKBP & $54 \%$ & 54 \\
\hline Man & $\begin{array}{l}\text { FKBP of human cancer } \\
\text { cell line }\end{array}$ & $53,4 \%$ & 27 \\
\hline Neurospora crassa & FKBP & $50,8 \%$ & 53 \\
\hline
\end{tabular}

1 The sequence of th C-terminal part of the $\mathrm{L} 2$ protein was used for comparison.

2 FK506 binding protein. 
exhibited PPIase activity which could be inhibited by FK506 in a nanomolar range (18). Presently studies are underway to decide whether or not this particular enzymatic activity contributes to the pathogenicity of Legionella.

\section{Molecular Cloning of Other Putative Virulence Factors}

Besides the Mip protein, several other Legionella antigens were identified and characterized which may function as virulence factors (see Table 2). A recently done by Engleberg and others (16) the $19 \mathrm{kDa}$ peptidoglycan-associated protein of Legionella (Ppl) has been cloned and sequenced in our laboratory (31). This protein is associated with the murein layer of the bacterial surface and exhibits a distinct homology to lipoproteins of E. coli and Haemophilus influenzae. The role of Ppl in pathogenicity of legionellae has to be established yet.

The major outer membrane protein (MOMP) of L. pneumophila has been previously cloned (24). The MOMP protein binds the $\mathrm{C} 3$ factor of the complement, thereby mediating the macrophageal engulfment of Legionella (3). The gene ompS encodes the $28 \mathrm{kDa}$ protein which also can be covalenty linked to peptidoglycan, forming a structure of $31 \mathrm{kDa}$. Oligomers of $28 \mathrm{kDa}$ and $31 \mathrm{kDa}$ form a complex of $100 \mathrm{kDa}$ which can be isolated from Legionella surfaces $(24,25)$. The MOMP complex is further

Table 2. L. pneumophila genes cloned in E. coli $\mathrm{K}-12$

\begin{tabular}{|c|c|c|c|c|}
\hline Gene & $\begin{array}{l}\text { Mol. weight } \\
\text { of the protein }\end{array}$ & Function/Description & $\begin{array}{l}\text { Contribution } \\
\text { to pathogenicity }\end{array}$ & References \\
\hline mip & $24 \mathrm{kDa}$ & $\begin{array}{l}\text { "macrophage infectivity } \\
\text { potentiator", involved in } \\
\text { intracellular survival, } \\
\text { PPIase activity }\end{array}$ & + & $10,11,18$ \\
\hline$m s p$ & $38 \mathrm{kDa}$ & $\begin{array}{l}\text { "major secretory protein" } \\
\text { metallo-protease, cytotoxic } \\
\text { and hemolytic activity }\end{array}$ & - & $5,29,51$ \\
\hline lly & $39 \mathrm{kDa}$ & $\begin{array}{l}\text { "legiolysin", hemolytic } \\
\text { activity, involved in } \\
\text { pigment production }\end{array}$ & - & 56 \\
\hline$p p l A$ & $19 \mathrm{kDa}$ & $\begin{array}{l}\text { "peptidoglycan-associated } \\
\text { protein of Legionella" }\end{array}$ & n.d. & 16,31 \\
\hline$o m p S$ & $\begin{array}{l}28 \mathrm{kDa}- \\
31 \mathrm{kDa}\end{array}$ & $\begin{array}{l}\text { Major outer membrane protein } \\
\text { (MOMP), } 100 \mathrm{kDa} \text { complex, } \\
\text { involved in uptake of legionellae } \\
\text { by C3-opsonization, attachment }\end{array}$ & + & $3,24,25$ \\
\hline$b t p \mathrm{~B}$ & $60 \mathrm{kDa}$ & $\begin{array}{l}\text { "Heat shock proteins", house- } \\
\text { keeping functions }\end{array}$ & n.d. & $22,23,46$ \\
\hline $\operatorname{sod} \mathrm{B}$ & n.d. & Iron-superoxide dismutase & n.d. & 50 \\
\hline$r e c \mathrm{~A}$ & $38 \mathrm{kDa}$ & $\begin{array}{l}\text { homologous recombination } \\
\text { UV-induced }\end{array}$ & n.d. & .57 \\
\hline
\end{tabular}

n.d., not determined.

2.3 Zbl. Bakt. 278/2-3 
involved in an opsonization-independent attachment to human cells (44). Furthermore, the $60 \mathrm{kDa}$ heat shock protein (Htp) of L. pneumophila was cloned by Hoffman et al. and other groups $(20,22,46)$. It is immunodominant, displaying homology to the groEL family of heat shock proteins (23). Mutations in the btp locus indicating that the "house-keeping" functions of this protein would make it indispensable for the bacterium could not be obtained.

Two hemolytic proteins have been cloned, and one of them, the Msp (major secretory protein) is $38 \mathrm{kDa}$ metallo-protease for which also cytotoxic effects on CHO cells have been demonstrated $(5,29)$. On the other hand, Msp-negative mutants remain virulent (51). The other hemolytic protein, legiolysin ( $\mathrm{Lly}$ ), was intensively studied in our laboratory. The $39 \mathrm{kDa}$ protein expressed in $E$. coli $\mathrm{K}-12$ exhibited brown pigment production in addition to hemolysis (56). Recently, an iron-superoxide dismutase which may be involved in the defence against the intracellular attack has been cloned from L.pneumophila (50). Additionally, the $38 \mathrm{kDa}$ RecA homologous protein of L. pneumophila was cloned (57) and shown to have functions similar to the E. coli RecA protein.

The cloned genes of L. pneumophila were also useful for differentiation of L.pneumophila strains from isolates of other species. DNA probes derived from the legiolysin (lly) and the peptidoglycan-associated protein of Legionella ( $p p l$ ) were used in the study of a large number of strains. We found that under conditions of high stringency hybridization, L. pneumophila reacted exclusively with these DNA probes. By applying low stringency conditions for hybridization, the genus Legionella could be differentiated from other Gram-negative bacteria $(4,40)$.

\section{Construction of Genomic Mutants}

Genetic attempts to analyse putative virulence factors of legionellae were hindered by numerous obstacles. Legionellae harbor a restriction system which functions as a defense against incoming DNA (35). Heterologous transfer of plasmids can only be achieved via conjugation and at relatively low frequency. Counterselection necessary for the isolation of trans-conjugants is restricted to a narrow spectrum of antibiotic resistance (37). To date, random transposon mutagenesis did not lead to an identification of virulence factors with the result that factors other than those obtained in the E. coli K-12 system (see above) have not been identified genetically. Genomic mutations were created by allelic exchange mutagenesis using the cloned genes. One of the approaches had been the use of mobilizable pir-dependent plasmids from the incX group (51). These were shown to be transferred to Legionella. They do not replicate due to the lack of the Pir protein in the recipient. Mutations can be therefore obtained by selecting the recombinational event concomitantly with the introduction of an antibiotic resistance marker. Experiments utilizing Col E1-derived plasmids for mutagenesis via allelic exchange have also been succesfully reported (11).

We inserted a kanamycin resistance gene into the legiolysin-coding sequence. The respective fragment was subcioned into pMSS 704-1. This plasmid is a derivative of the pir-dependent R6K (52) carrying an additional chloramphenicol resistance marker. Heterospecific conjugation was carried out between the $\operatorname{pir}^{+}$E. coli donor in which the genetic manipulations had been performed and a restriction-deficient derivative of the L. pneumophila Philadelphia I strain, JR 32 (35). Mobilization of the construct was achieved through the chromosomal tra function of the $E$.coli donor which acted upon 
the mob sequences present on the plasmid. Trans-conjugants were selected by streptomycin resistance (for the recipient L. pneumophila JR 32) and kanamycin resistance for allelic exchange of the wild type lly locus with the mutant DNA. Integration of the plasmid was excluded by the chloramphenicol-sensitive phenotype of the trans-conjugants (Fig. 1).

The mutants obtained were characterized genetically and phenotypically showing that disruption of the $l l y$ gene by the insertion of kanamycin resistance resulted in a loss of brown pigment production. Interestingly, a marked influence on the hemolytic activity of the mutant could not be observed. This has been explained by the fact that L. pneumphila carries additional hemolytic factors which may mask the hemolytic activity of the legiolysin (6). Reintroduction of intact lly sequences by transferring them via a stable replicating $\mathrm{pMMB} 34$ derivative (incQ) resulted in restoration of brown pigment production. The influence of the lly mutation was also tested in models for intracellular replication of Legionella.

\section{Cellular Models for Intracellular Replication}

Various cellular models for intracellular replication of Legionella have been established. It could be shown that human cell lines are appropriate for this purpose. These include HeLa cells (14), Hl 60 monocytes (34) and U 937 macrophage-like cells (42). In addition, recent data have shown that protozoan models such as Acanthamoeba castellanii are especially useful in the differentiation of virulent from avirulent variants (38,
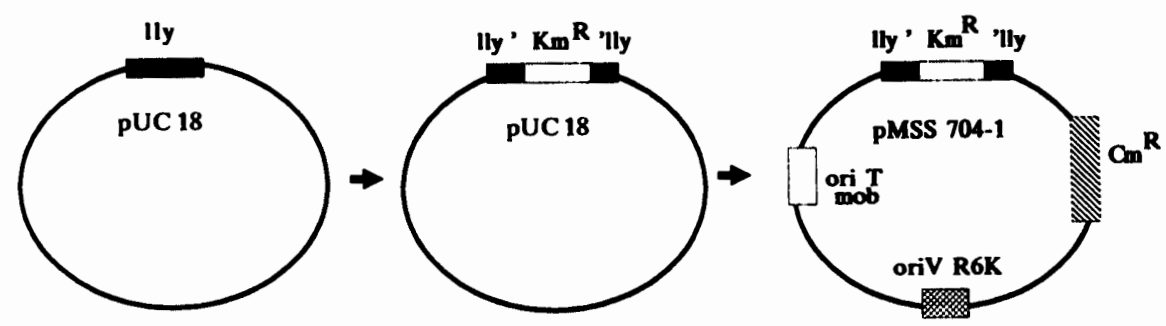

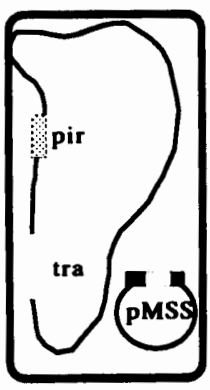

E. coli K-12

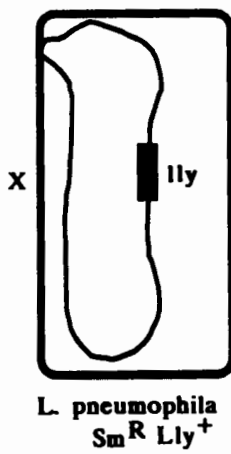

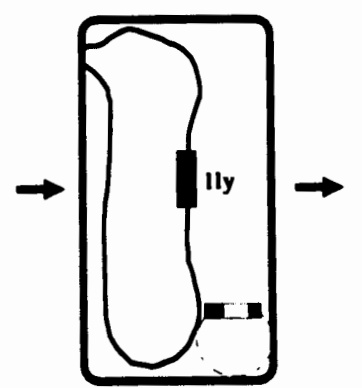

Sm ${ }^{\text {Lly }}{ }^{+}$

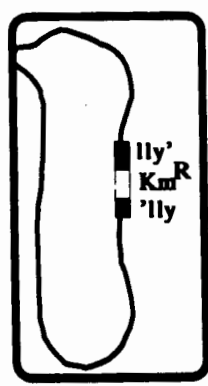

L. poeumophila $\operatorname{Sin}^{\text {R }}$ Lly $^{-}$

Fig. 1. Construction of a $\mathrm{Lly}^{-}$mutant of L.pneumophila Philadelphia I (JR 32) by allelic exchange. 


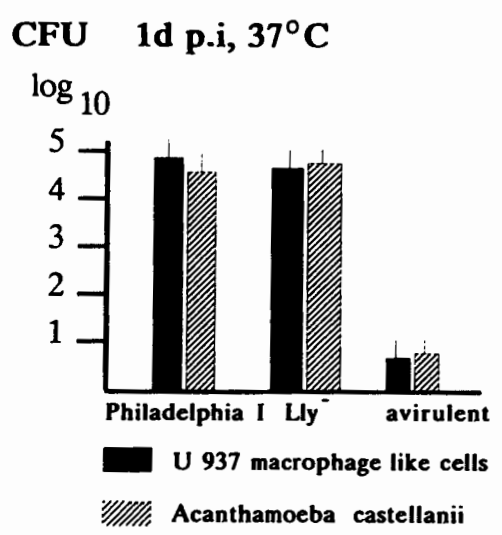

Fig. 2. Intraceilular growth behavior of L.pneumophila Philadelphia I, an avirulent derivative (XXXV), and the Lly ${ }^{-}$mutant in U937 macrophage-like cells and A. castellanii grown at $37^{\circ} \mathrm{C}$. Mean CFU values (with standard deviation) determined $1 \mathrm{~d}$ after infection are given.

49). We tested the Lly-negative L.pneumophila mutant for intracellular growth in U 937 macrophage-like cells and in A.castellanii. The invasion assay begins with the centrifugation of the legionellae onto the host cells and an incubation for 2 hours, so that legionellae can establish themselves intracellularily. Hereafter, the supernatant is removed and remaining extracellular legionellae are killed by gentamicin treatment $(80 \mu \mathrm{g} / \mathrm{ml})$ applied for one hour. After washing, fresh antibiotic free-medium is added. Colony-forming units of viable legionellae are counted at time " $\mathrm{O}$ ", i. e. directly after gentamicin treatment, 3 and 1 day after infection (p. i.), by plating serial dilutions of the disrupted cultures on special Legionella medium.

The tests were performed using the virulent Philadelphia I strain, an avirulent derivative (XXXV) and the Lly-negative mutant at $37^{\circ} \mathrm{C}$. In Fig. 2 it can be seen that $1 \mathrm{~d}$ p. i., the Lly-negative mutant "displayed intracellular CFU values" similar to those obtained for the virulent Philadelphia parent. From these data, we conclude that the legiolysin has no influence on intracellular replication of L.pneumophila. Perhaps the involvement of $l l y$ in pigment production confers an advantage to legionellae with regard to their survival in the environmental reservoir. Fig. 3 illustrates the intracellular location of legionellae in phagosomes of U 937 cells and, during the later stage of the intracellular life cycle, in the cytoplasm. Since the growth temperature had been reported to have an influence on the survival of L. pneumophila in A. castellanii (38), the strains were further tested at $30^{\circ} \mathrm{C}$ with $A$. castellanii as a host (Table 3 ). It could be shown that the avirulent derivative of the Philadelphia I strain was also capable of growth in Acanthamoeba at $30^{\circ} \mathrm{C}(49)$.

Acknowledgements. Our own studies included in this work were supported by the Bundesministerium für Forschung und Technologie (BMFT $01 \mathrm{~K} ; 8829$ ). We gratefully acknowledge the critical comments of Laurence R.E.Phillips and the editorial assistance of H. Kurz. 

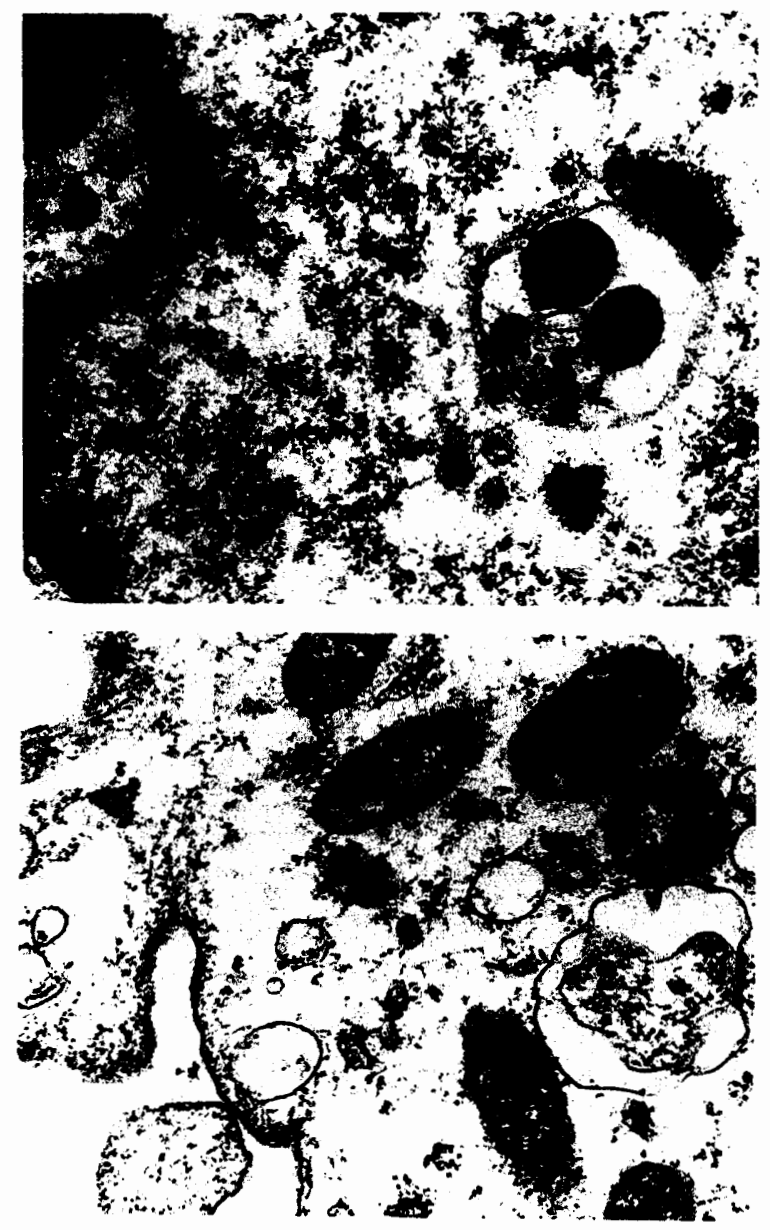

Fig. 3. Electronmicroscopic examination of thin sections of U937 cells infected by legionellae. The intracellular location of L.pneumophila in phagosomes (above) in the early stage of invasion is shown (magnification $20000 \times$ ). In a later stage of the intracellular life cycle, legionellae are found in the cytoplasm (below, magnification $30000 \times$ ).

Table 3. Intracellular growth behavior and in vivo virulence of L.pneumophila Philadelphia I and derivatives

\begin{tabular}{|c|c|c|c|c|}
\hline \multirow[t]{2}{*}{ Strain } & \multicolumn{3}{|c|}{$\begin{array}{l}\text { Intracellular growth in } \\
\text { U } 937 \text { cells } A \text {. castellanii }\end{array}$} & \multirow[t]{2}{*}{$\begin{array}{l}\text { in vivo virulence (i.p. } \\
\text { infection of guinea pigs) }\end{array}$} \\
\hline & & $30^{\circ} \mathrm{C}$ & $37^{\circ} \mathrm{C}$ & \\
\hline $\begin{array}{l}\text { L.pneumophila } \\
\text { Philadelphia I }\end{array}$ & + & + & + & + \\
\hline $\begin{array}{l}\text { L.pneumophila } \\
\text { XXXV, avirulent }\end{array}$ & - & + & - & - \\
\hline $\begin{array}{l}\text { L.pneumophila } \\
\text { JR } 32, \text { Lly }^{-}\end{array}$ & + & + & + & n.d. \\
\hline
\end{tabular}

n.d., not determined. 


\section{References}

1. Bangsborg, J.M., N.P.Cianciotto, and P. Hindersson: Nucleotide sequence analysis of the Legionella micdadei mip gene, encoding a 30-kilodalton analog of the Legionella pneumophila mip protein. Infect. Immun. 59 (1991) 3836-3840

2. Baskerville, A., R.B. Fitzgeorge, M. Broster, P.Hambleton, and P.J. Dennis: Experimental transmission of Legionnaires' disease by exposure to aerosols of Legionella pneumophila. Lancet 2 (1981) 1389-139

3. Bellinger-Kawahara, C. and M. A. Horwitz: Complement component C3 fixes selectively to the major outer membrane protein (MOMP) of Legionella pneumophila and mediates phagocytosis of liposome-MOMP complexes by human monocytes. J. Exp. Med. 172 (1990) 1201-1210

4. Bender, L., M. Ott, A. Debes, U. Rdest, J. Heesemann, and J: Hacker: Distribution, expression and long range mapping of Legiolysin gene (lly) specific DNA sequences in legionellae. Infect. Immun. 59 (1991) 3333-3336

5. Black, W.J., F.D. Quinn, and L.S. Tompkins: Legionella pneumophila zinc metalloprotease is structurally and functionally homologous to Pseudomonas aeruginosa elastase. J. Bact. 172 (1990) 2608-2613

6. Bornstein, N., M. Nowicki, and J. Fleurette: Haemolytic activity in the genus Legionella. Ann. Inst. Pasteur/Microbiol. (Paris) 139 (1988) 325-329

7. Caparon, M. and W.Johnson: Macrophage toxicity and complement sensitivity of virulent and avirulent strains of Legionella pneumophila. Rev. Infect. Dis. 10 Suppl. (1988) S 377-381

8. Catrenich, C.E. and W.Johnson: Virulence conversion of Legionella pneumophila: a one-way phenomenon. Infect. Immun. 56 (1988) 3121-3125

9. Cianciotto, N.P., J.M. Bangsborg, B. I. Eisenstein, and N. C. Engleberg: Identification of mip-like genes in the genus Legionella. Infect. Immun. 58 (1990) 2912-2918

10. Cianciotto, N.P., B.I. Eisenstein, C.H.Mody, and N.C. Engleberg: A mutation in the mip gene results in attenuation of Legionella pneumophila virulence. J. Infect. Dis. 162 (1990) $121-126$

11. Cianciotto, N.P., B.I.Eisenstein, C.H.Mody, G.B.Toews, and N.C.Engleberg: A Legionella pneumophila gene encoding a species-specific surface protein potentiates initiation of intracellular infection. Infect. Immun. 57 (1989) 1255-1262

12. Dennis, P.J. and J. V. Lee: Differences in aerosol survival between pathogenic and nonpathogenic strains of Legionella pneumophila serogroup 1. J. Appl. Bact.65 (1988) $135-141$

13. Dowling, J.N., A.K. Saha, and R.H. Glew: Virulence factors of the family Legionellaceae. Microbiol. Rev.56 (1992) 32-60

14. Dreyfus, L. A.: Virulence associated ingestion of Legionella pneumophila by HeLa cells. Microb. Pathogen. 3 (1987) 45-52

15. Engleberg, N.C., C. Carter, D.R. Weber, N.P. Cianciotto, and B. I. Eisenstein: DNA sequence of mip, a Legionella pneumophila gene associated with macrophage infectivity. Infect. Immun. 57 (1989) 1263-1270

16. Engleberg, N. C., D. C. Howe, J. E. Rogers, J. Arroyo, and B. I. Eisenstein: Characterization of a Legionella pneumophila gene encoding a lipoprotein antigen. Molec. Microbiol. 5 (1991) 2021-2029

17. Engleberg, N.C., E.Pearlman, and B.I. Eisenstein: Legionella pneumophila surface antigens cloned and expressed in Escherichia coli are translocated to the host cell surface and interact with specific anti-Legionella antibodies. J. Bact. 160 (1984) 199-203

18. Fischer, G., H.Bang, B.Ludwig, K. Mann, and J.Hacker: Mip protein of Legionella pneumophila exhibits peptidyl-prolyl-cis/trans isomerase (PPIase) activity. Molec. Microbiol. 6 (1992) 1375-1383

19. Fischer, G. and F. X. Schmid: The mechanism of protein folding. Implications of in vitro refolding models for de novo protein folding and translocation in the cell. Biochemistry 29 (1990) 2205-2212 
20. Hacker, J., M. Ott, B. Ludwig, and U.Rdest: Intracellular survival and expression of virulence determinants of Legionella pneumophila. Infection 19 Suppl. (1991) 198-201

21. Hindahl, M.S. and B.H. Iglewski: Cloning and expression of a common Legionella outer membrane antigen in Escherichia coli. Microb. Pathogen. 2 (1987) 91-99

22. Hoffman, P.S., C. A.Butler, and F. C. Quinn: Cloning and temperature-dependent expression in Escherichia coli of a Legionella pneumophila gene coding for a genuscommon 60-kilodalton antigen. Infect. Immun. 57 (1989) 1731-1739

23. Hoffman, P.S., L.Houston, and C.A.Butler: Legionella pneumophila htpAB heat shock operon: nucleotide sequence and expression of the 60-kilodalton antigen in L. pneumophila-infected HeLa cells. Infect. Immun. 58 (1990), 3380-3387

24. Hoffman, P.S., M. Ripely, and W. Weeratna: Cloning and nucleotide sequence of a gene (ompS) encoding the major outer membrane protein of Legionella pneumophila. J. Bact. 174 (1992) 914-920

25. Hoffman, P.S., J.H. Seyer, and C.A.Butler: Molecular characterization of the 28- and 31-kilodalton subunits of the Legionella pneumophila major outer membrane protein. J. Bact. 174 (1992) $908-913$

26. Horwitz, M. A.: Characterization of avirulent mutant Legionella pneumophila that survive but do not multiply within human monocytes. J. Exp. Med.166 (1987) $1310-1328$

27. Jin, Y.J., M. W.Albers, W.S.Lane, B.E.Bierer, S.L.Schreiber, and S. J.Burakoff: Molecular cloning of a membrane-associated human FK506- and rapamycin-binding protein, FKBP-13. Proc. Natl. Acad. Sci. USA 88 (1991) 6677-6681

28. Kato, J., L.Chu, K.Kitano, J.D.de Vault, K.Kimbara, A.M. Chakrabarty, and T. K. Misra: Nucleotide sequence of the regulatory region controlling alginate synthesis in Pseudomonas aeruginosa: Characterization of the alg R2 gene. Gene 84 (1989) $31-38$

29. Keen, M. G. and P.S. Hoffman: Characterization of a Legionella pneumophila extracellular protease exhibiting hemolytic and cytotoxic activities. Infect. Immun. 57 (1989) $732-738$

30. Lang, K., F. X. Schmid, and G. Fischer: Catalysis of protein folding by prolylisomerase. Nature 329 (1987) 268-270

31. Ludwig, B., A.Schmid, R. Marre, and J.Hacker: Cloning, genetic analysis, and nucleotide sequence of a determinant coding for a 19-kilodalton peptidoglycan-associated protein ( $p p l$ ) of Legionella pneumophila. Infect. Immun. 59 (1991) 2515-2521

32. Lundemose, A. G., S. Birkelund, S. J. Fey, P. Moselarsen, and G. Christiansen: Chlamydia trachomatis contains a protein similar to the Legionella pneumophila mip gene product. Molec. Microbiol. 5 (1991) 109-115

33. Maki, N., F.Sekiguchi, J.Nishimaki, K.Miwa, T.Hayano, N.Takahashy, and M. Swzutei: Complementary DNA encoding the human T-cell FK 506-binding protein, a peptidylprolyl cis-trans isomerase distinct from cyclophilin. Proc. Natl. Acad. Sci. USA 87 (1990) 5440-5443

34. Marra, A., M. A. Horwitz, and H. A. Shumann: The HL-60 model for the interaction of human macrophages with the Legionnaires' disease bacterium. J. Immunol. 144 (1990) $2738-2744$

35. Marra, A. and H. A. Shumann: Isolation of a Legionella pneumophila restriction mutant with increased ability to act as recipient in heterospecific matings. J. Bact. 171 (1989) $2238-2240$

36. McDade, J.E., C. C. Shepard, D. W. Fraser, T. R. Tsai, M. A. Redus, and W.R. Dowdle: Legionnaires' disease: isolation of a bacterium and demonstration its role in other respiratory disease. N. Engl. J. Med. 297 (1977) 1197-1203

37. Mintz, C.S. and H. A. Shumann: Genetics of Legionella pneumophila. Microbiol. Sci. 5 (1988) 292-295

38. Moffat, J.F. and L.S. Tompkins: A quantitative model of intracellular growth of Legionella pneumophila in Acanthamoeba castellanii. Infect. Immun. 60 (1992)

$296-301$ 
39. Nowicki, M., N. Bornstein, J. C. Paucod, P. Binder, and J. F. Fleurette: Effect of culture medium on morphology and virulence of Legionella pneumophila serogroup 1. Zbl. Bakt. Hyg. A 264 (1987) 167-177

40. Ott, M., L. Bender, E. Chirinos, W. Ehret, and J. Hacker: Phenotype versus genotype of the $19 \mathrm{kD}$ peptidoglycan associated protein of Legionella (PplA) among legionellae and other gram-negative bacteria. Microb. Pathogen. 11 (1991) 357-365

41. Ott, M., L.Bender, R.Marre, and J.Hacker: Pulsed field electrophoresis of genomic restriction fragments for the detection of nosocomial Legionella pneumophila in hospital water supplies. J. Clin. Microbiol. 29 (1991) 813-815

42. Pearlman, E., A.H.Jiwa, N.C. Engleberg, and B.I. Eisenstein: Growth of Legionella pneumophila in a human macrophage-like (U937) cell line. Microb. Pathogen. 5 (1988) 87-95

43. Perry, A.C.F., I.J. Nicolson, and J.R. Saunders: Neisseria meningitidis C114 contains silent, truncated pilin genes that are homologous to Neisseria gonorrhoeae pil sequences. J. Bact. 170 (1988) 1691-1697

44. Quinn, F. D., C. A. Butler, and P.S. Hoffman: Characterization and cloning of the disulfide-cross-linked major outer membrane protein of Legionella pneumophila $\mathrm{H} 116$. J. Cell. Biochem. 262 (1987) 116-120

45. Rowbotham, T. J.: Current views on the relationship between amoebae, legionellae, and man. Isr. J. Med. Sci. 22 (1986) 678-689

46. Sampson, J.S., S.P.O'Connor, B.P.Holloway, B.B.Plikaytis, G.M.Carlone, and L. W. Mayer: Nucleotide sequence of $h t p B$ the Legionella pneumophila gene encoding the 58-kilodalton $(\mathrm{kDa})$ common antigen, formerly designated the $60-\mathrm{kDa}$ antigen. Infect. Immun. 58 (1990) 3154-3157

47. Schreiber, S. L.: Chemistry and biology of the immunophilins and their immunosuppressive ligands. Science 251 (1991) 283-287

48. Standaert, R.F., A. Galat, G.L.Verdine, and S.L.Schreiber: Molecular cloning and overexpression of the human FK506-binding protein FKBP. Nature 346 (1990) 671-674

49. Steinert, M., M. Ott, L. Bender, E. Chirinos, P. C. Lück, and J. Hacker: Analysis of virulent and avirulent Legionella pneumophila: protein profiles, intracellular replication in Acanthamoeba castellanii and U 937 macrophage-like cells and guinea pig infectivity. Microb. Pathogen., submitted

50. Steinman, H. M.: Construction of an Escherichia coli K-12 strain deleted for manganese and iron superoxide dismutase gene and its use in cloning the iron superoxide dismutase gene of Legionella pneumophila. Molec. Gen. Genet. 232 (1992) 427-430

51. Szeto, L. and H.A.Shuman: The Legionella pneumophila major secretory protein, a protease, is not required for intracellular growth or killing. Infect. Immun. 58 (1990) 2585-2592

52. Taylor, R. K., C. Manoil, and J.J.Mekalanos: Broad-host range vectors for delivery of TnphoA: use in genetic analysis of secreted virulence determinants of Vibrio cholerae. J. Bact. 171 (1989) 1870-1878

53. Tropschug, M., E. Wachter, S. Mayer, E.R. Schönbrunner, and F.X. Schmid: Isolation and sequence of an FK 506-binding protein from $N$. crassa which catalyses protein folding. Nature 346 (1990) 674-677

54. Wiederrecht, G., L. Brizuela, K. Elliston, N. H. Sigal, and J.J. Siekierka: FKBP1 encodes a non essential FK506-binding protein in Saccharomyces cerevisiae and contains regions suggesting homology to the cyclophilins. Proc. Natl. Acad. Sci. USA 88 (1991) 1029-1033

55. Winn, W. C.: Legionnaires' disease: historical perspective. Clin. Microbiol. Rev. 1 (1988) 60-81

56. Wintermeyer, E., U.Rdest, B.Ludwig, A.Debes, and J.Hacker: Characterization of legiolysin (lly), responsible for haemolytic activity, colour production and fluorescence of Legionella pneumophila. Molec. Microbiol. 5 (1991) 1135-1143

57. Zhao, X. and L.A.Dreyfus: Expression and nucleotide sequence analysis of the Legionella pneumophila recA gene. FEMS Microbiol. Lett. 70 (1990) 227-232

Professor Dr. Jörg Hacker, Theodor-Boveri-Institut für Biowissenschaften, Lehrstuhl für Mikrobiologie, Röntgenring 11, D-8700 Würzburg 